\title{
Gandhian from the history of Collections of the Cultural Heritage of Uzbekistan Abroad
}

\author{
Jannat Khamidovna Ismailova ${ }^{1}$ \\ ${ }^{I}$ Doctor of historical sciences professor \\ Director of the State Museum of History of Uzbekistan. Uzbekistan \\ Email: jannat.ismailova@mail.ru
}

\begin{abstract}
For centuries, Uzbekistan has been known as a scientific, commercial and cultural center in the center of the East and a region at the crossroads of the Great Silk Road. During the historical period, the cultural heritage of the Uzbek people was taken abroad for various reasons, which later led to the formation of collections in world-famous libraries and museums under the name of Central Asia. Many travelers and scientists were interested in the geographical location, nature, customs, industries of the region, organized various expeditions and published scientific works.

This article provides information about the activities of scientists, travelers and photographers who came to Central Asia from the second half of the XIX century, the process of formation of collections.

Keywords: Central Asia, Bukhara, Hermitage Museum, traveler, artifacts, collection, archeology, ethnography, photographer.

\section{INTRODUCTION}

In the pages of the history of Uzbekistan, researchers have studied the historical processes of the second half of the XIX century and the beginning of the XX century. However, there are still topics that have not been studied in depth as separate research, and the topic we present today is one of such objects. Until now, Uzbekistan has been studied in general about the representatives of various fields, scientists, tourists who came from abroad at that time and conducted research, and their activities have not been studied separately. The reasons for the entry of each person into Central Asia, the field, the collections he collected, the research work and publications, the comprehensive research work on the history of the formation of Central Asian collections abroad determine the relevance of the topic.
\end{abstract}

\section{RESEARCH METHODS}

The study explores the mechanism of formation of oriental collections in Russia and other museums from archival sources, historical data, memories based on the principles of comparative-logical, sequential, impartiality.

\section{RESULTS}

Cultural monuments of Uzbekistan are preserved in the world's museums and libraries as the most unique artifacts. The formation of the oriental collections available in each museum is formed for reasons such as the activities of different collectors, the results of research. One such museum, the Museum of Anthropology and Ethnography, is known as the largest treasure trove of manuscripts, 
documents, photographs, and artifacts in the world. The collections here are mostly collected by travelers and researchers.

Interest in the history and culture of Central Asia, as well as the collection of documents and artifacts began in the XVIII century. The first collections were formed in the Kunstkamera Museum in Russia. It is called the "Unique Caspian Sea Collection" of the first half of the XVIII century. The collection consisted of mosques, manuscripts on parchment paper with various incomprehensible inscriptions, and items. It is assumed that these collections were roughly commissioned by the Bekovich-Cherkassky militarytopographic expedition. This expedition collected a number of cultural monuments as it marched along the banks of the Amu Darya in search of a convenient port on the Caspian Sea ${ }^{[1]}$.

This information is given in the catalog of the museum, published in 1741. This catalog contains information about the presence of Bukhara shoes in the Asian collection before the fire in the museum. Unfortunately, these items are not found in later collections $\left[{ }^{2}\right]$.

The name of the state adviser Yakov Yakovlevich Lyuchshe (Lyutshe, Lyutsh) is often used in several literature and archival documents. In 1903 he worked as a Russian diplomatic agent in the Emirate of Bukhara.

This position gave him the right to be a world judge in relation to Russian citizens in Bukhara. The post was later renamed the Russian Political Agent. The Emir of Bukhara had long opposed the establishment of Russian control in Bukhara. In 1908 a police chief was established in the city, and in 1911 a Russian police department was established.

According to the information, during the visit of the Emir of Bukhara Alimkhan to St. Petersburg in 1906, he was accompanied by Ya.Ya. Lyuchshe. Ya.Ya.Lyuchshe is actually known as the largest collector of oriental manuscripts as a graduate of the Oriental Faculty of St. Petersburg University. Living in Central Asia and deeply acquainted with the way of life and culture of the people, this man handed over to the archives of the Institute of Oriental Studies in St. Petersburg valuable historical and literary heritage [3].

In the photos in the museum's photo fund, you can see the history stamped on photos and documents for centuries. Indeed, the pictures, which contain the historical environment of different periods not reflected in the books, serve as a great source in imagining the environment of that period.

The museum's illustration fund consists of 550 collections, including $(50,000)$ photographs, drawings, glass and film negatives, photographs and postcards, as well as photo albums.

These collections are divided into groups and provide information about the social life of various nations and peoples living in Central Asia in the late XIX - early XX centuries, such as Uzbeks, Kazakhs, Tajiks, Turkmens, Kyrgyz, Dungans, Jews, Uighurs, Gypsies [4]. The collection also includes portraits of khans, beys, tribal chiefs, priests, representatives of local administrations, craftsmen, and theater artists. There are also collections that cover areas such as people's lifestyles, culture, trade, historical and cultural events, transportation, applied arts, religion, music, architecture, customs.

When it comes to the first collections, it should be noted that the formation of the first collections was closely associated with travelers. Before the advent of photography, travelers on expeditions tried to depict situations and historical landscapes that were not included in the texts with pencil and watercolor. During the 19th century, famous Russian travelers organized many expeditions to Central Asia. If the expedition participants did not know how to draw, they would definitely take the artist with them. But 
because the work of collecting and collecting such photographs was not taken seriously in time, they are now preserved in very small quantities.

The emergence of photography has greatly increased the interest of the whole society in this field. Naturally, the introduction of photography into the field of science was a major factor in the complete data collection of expeditions. By 1848, the advent of glass negatives made it possible to make photographs in multiple copies.

Thus, several albums related to the life and lifestyle of the Turkestan region were released. One of them is the album "Vidy i tipy Khivinskogo khanstva" prepared by lieutenant G.Krivtsov, which he did on behalf of K.P.Kaufman. G.Krivtsov was a very good photographer, and his photos were regularly published in the pages of the yearbook "Materials for the geography and statistics of the Turkestan region." The lithography was performed by E. Arngold, and the album was received in 1874 by the Museum of Anthropology and Ethnography. [5]. This album consisted of 78 pages, 39 photos, the quality of which was very high. G.E.Krivtsov was well acquainted with the history of the Khiva khanate. That is why in the papyrus paper on the back of each photo was given a detailed description of the way of life and historical aspects of the people of the region.

The essence of the content of the album is mainly described the attractions, streets and markets of Khiva, as well as the Khiva administration and influential representatives.

Samuel Martynovich Dudin-Martsinkevich (1863-1929) was a collector, painter, graphic artist, archaeologist, ethnographer, and photographer. It was he who founded scientific ethnographic photography in Russia. S.M.Dudin conducted research in the circle of V.V.Radlov the Russian Committee for the Study of Central and East Asia, along with well-known archaeologists and ethnographers. In many expeditions S.M. Dudin participated as an assistant to such scientists as academician V.V.Radlov, S.F.Oldenburg, V.V.Bartold, professors N.I.Veselovsky, L.Ya.Shternberg. His artefacts have enriched the funds of many museums, including the Hermitage, the Russian Ethnographic Museum, the Academy of Arts and the Museum of the History of Uzbekistan [6].

For many years, S.M. Dudin worked as a scientist and treasurer in the Department of Antiquities of East and West Turkestan of the Museum of Anthropology and Ethnography since 1891. He formed a collection of artifacts and photographs on the traditional culture of Central Asia. Dudin, who worked for the Archaeological Commission of the Russian Committee, collected ethnographic artifacts from across Turkestan, including weapons, clothing, household items, carpets, and alabaster architectural ornaments. During his work in the museum, he collected photographs, as well as collected a number of ethnographic and archeological artifacts during his annual expeditions to Turkestan in 1900-1909.

Dudin's collection consists of more than 4,000 exhibits dedicated to Uzbeks, Tajiks, Turkmens and Kyrgyz. They consisted of 35 collections, 1,500 photographs, 15 photo collections [7]. During his career, Dudin visited Turkestan several times on behalf of the Russian Committee. He studied several historical and architectural monuments. He took photos of them and collected architectural ornaments.

The museum has long preserved more than 1,000 materials related to the Afrosiab architectural monument. Later, most of it was given to the Hermitage.

In 1905-1907 he went to Samarkand. He conducted excavations in Shahi-Zinda and collected and handed over a collection of ancient Central Asian pottery for the Fund of Anthropology and Ethnography, 
Russian Museums. In 1912, Dudin again presented a collection of 260 negatives, consisting of a view of the general and individual details of the Shohi-Zinda monument [8].

In 1906, a large exhibition was organized in the building of the Academy of Sciences on the basis of a collection of photo negatives collected by him. This exhibition caused a great stir in society. Currently, the album and negatives of this exhibition are kept in the museum [9].

Heinrich Moser was born in 1814 in St. Petersburg. His father was a well-known watchmaker and had the famous watch shop in St. Petersburg. When Henry Moser was 5 years old, his father sent him to study in Switzerland, in Schaffhausen [10]. He retired after serving in the Swiss cavalry and returned to Russia in 1865.

Books about the travels of James Cook, Alexander Humboldt, and Petr Chikhachev boost 20year-old Henry Moser's passion for travel. For this reason he came to P.A. Chikhachev in December 1864. Henry, who dreamed of a sea voyage, decided to travel only by land after suffering from seasickness several times. In turn, Chikhachev told him about his travels to Siberia and Asia, as well as the importance of these expeditions. Henry Moser returned to St. Petersburg in 1865. It was at this time that Przewalski was planning an expedition to Assyria. But because of Henry's father's intervention, he is rejected. Nevertheless, he began his first voyage from Siberia in 1867 at his own expense. Reaches Orenburg in 1 month and learns Oriental languages with determination for 4 months. In 1868, despite the opposition of the governor of Orenburg, at night he set out for the deserts of Kazakhstan with several people, including the Kazakh Turgai Davlatkulov and the Uzbek Yusuf Absalyanov.[11] Travels through the deserts of Kazakhstan to Tashkent, Mazar-e-Sharif, Kokand, Margilan, Andijan and Chinese Turkestan in the Fergana Valley with little money and a good horse [12].

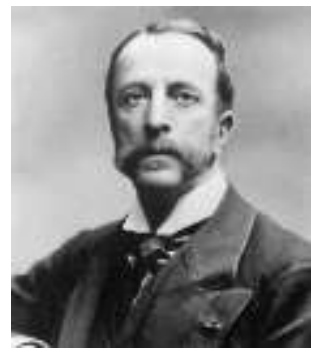

In 1869-1870, Henry Moser traveled along the Syrdarya to Turkestan, Shymkent, Tashkent, Samarkand and Bukhara. His third expedition was an 18-month voyage from 1882-1983, collecting his own memoirs and collections. In 1885 he published in the Geneva newspaper in the form of essays what he had seen during his travels. At the end of this year, he will publish all his memoirs in the form of an illustrated book "Across Central Asia." His first book is dedicated to the trip from Orenburg to Tashkent, and the second to Samarkand and Bukhara [13]. His articles on various topics are also published in French magazines and newspapers.

After the reception of the Emir of Bukhara, G.Mozer said goodbye to Ferdinand Wittgenstein, Alexander Sh's Ambassador to the Emir of Bukhara and started his travel through the Amudarya to the Petroalexandrov Fortress, and through it to the Khiva region, through Karakum to Ashgabat, from there to Tehran, through the Caspian Sea to Baku, and then through Constantinople to Europe.

Of the European travelers, only Henry Moser was able to enter the innermost part of Turkestan and leave a great mark in history as a person who wrote very beautiful impressions during his travels. 
In June 1887 we visited an exhibition dedicated to the countries of Central Asia in Lucerne. The exhibition consisted of 2 large halls, where items related to the lifestyle of the middle class were displayed. Among them were photographs of women's and men's clothing, various books, coins, dishes, carpets, weapons, cities, villages, caravans, and monuments.

The exhibition also sold 170 engravings, 16 heliotypes, and a card book. This book is "A travers l'Asie Centrale. La steppe Kirghise - le Turkestan Russe - Boukhara - Khiva - le pays des turcomans et la Perse. - Impressions of voyage by Henri Moser ». named after him, published in Paris by E. Plon [14].

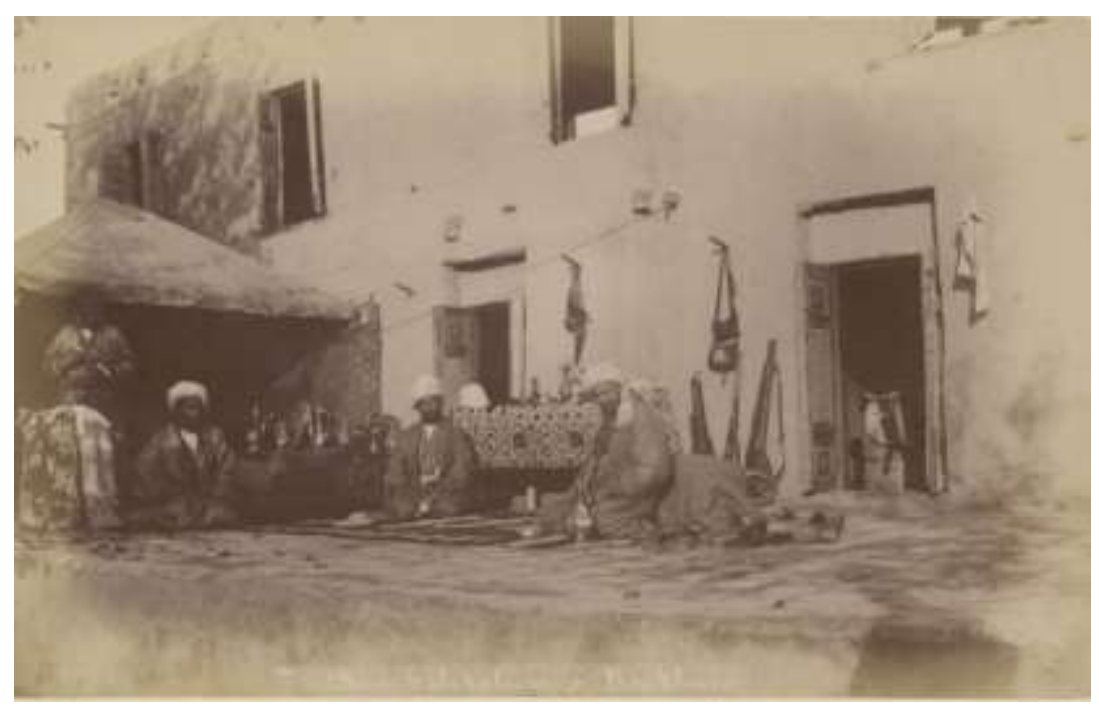

The place where lived G.Mozer in Bukhara.[15]

G.Moser's 4th expedition lasted from 1889 to 1890 . This time he crossed the Caspian Sea via Baku to Krasnovodsk, Ashgabat, Merv, and on his way back to the Trans-Caspian railway to Chorjoi, then to Bukhara, Samarkand and Tashkent.

G.Mozer, who experienced many hardships and adventures during his journey, liked to walk in local national costume. Suede jacket, red silk shirt, soft boots, Bukhara shawar, cashmere belt, hunting knife, revolver and sword [16].

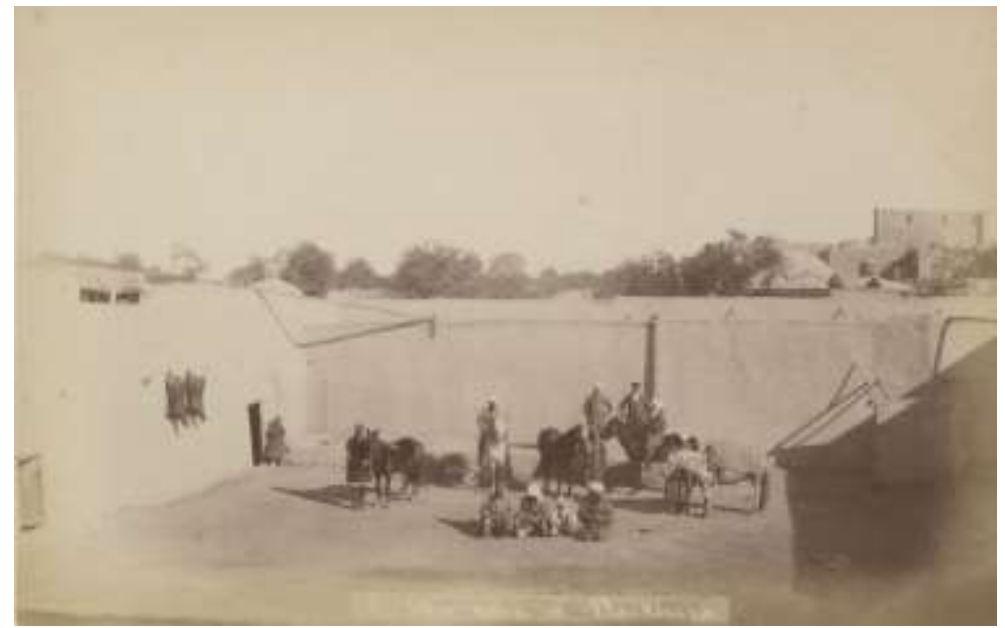

The house where G.Mozer lived in Bukhara.

G.Mozer, a holder of several prestigious European orders, the Order of the Legion of Honor and a member of 7 geographical societies, had a special attitude towards Russia and its travelers. This is evidenced, for example, by the opinions of travelers about N.M. Przhevalsky, who was ideal for him. 
Speaking of the spiritual and physical qualities of N.M. Przhevalsky, he describes him as a strong, healthy, sharp-sighted sniper, generous, and a man who shared a loaf of bread with his friends $\left[{ }^{1}\right]$.

According to sources, after his trip to Turkestan in 1869, he presented to the geographical community 3 Persian manuscripts brought from Samarkand.

Based on the collections collected over the years, G. Moser organized the Bosnia and Herzegovina pavilion in 1900 at the World's Fair in Paris.

By 1912 he was able to create a catalog of oriental collections based on his own collections. In 1914, he donated his collection to the Bern Museum, and in the same year became an honorary citizen of the city. In 1921, the museum opened a regular exhibition "Moser Anbau" [ $\left.{ }^{2}\right]$.

His collections are preserved in the castle of Charlottenfels in Shaff-Hausen, where, in addition to the items he collected during his travels, he bought artifacts from antique shops and auctions in Paris. Margaret Moser, a member of her family, said: "He spent most of his free time at the Druo Hotel, which is the largest auction house in Paris or on Lafayette Street. From shipments from the East, Armani Brimo and Moser were preoccupied with choosing a variety of items until 6 p.m. Every new discovery has been a source of great joy for Moser.

Indeed, Henry Moser's interest in Central Asia led him to study the lives of the local people over the years, collecting and disseminating a variety of materials about them. Through his efforts, he created unique collections about the peoples of Central Asia that have not lost their relevance not only in their time, but also today.

\section{CONCLUSION}

Thus, the strong interest of many scientists, tourists, experts of the world in Central Asia could not prevent them from covering long and arduous distances. The great achievements of the great scholars, statesmen, representatives of culture and art of the Uzbek people, who have made an invaluable contribution to the development of world civilization, have not only made the country world-famous, but also embraced it. As a result, many artifacts and manuscripts about the nature, population, history, culture, historical and architectural monuments, customs and traditions of the peoples of Central Asia have led to the formation of separate collections in foreign museums and the publication of hundreds of scientific publications.

\section{REFERENCES}

1.V.A.Prishchepova. From Lerxa to Zarubina.Iz istorii kollektsiy Kunstkamery po kulture narodov Tadjikistana. p.285.

2.V.A.Prishchepova. From Lerxa to Zarubina. From the history of the Kunstkamery collection on the culture of the peoples of Tajikistan. P.151

3.In the same place;

4.V. A. Prishchepova. Illyustrativnye kollektsii po narodam tsentralnoy Azii vtoroy poloviny XIXnach. XXv. In sobraniyax Kunstkamery. St. Petersburg "Science". 2011. p. 9

5.V. A. Prishchepova. Illyustrativnыe Kollektsii po narodam tsentralnoy Azii vtoroy poloviny

XIX- nach. XXv. In sobraniyax Kunstkamery. St. Petersburg.2011. p. 184

6.http://www.kunstkamera.ru/lib/

7.ARAN. F. 148.Op. 1. Ed. xr. 51.L. 39ob. MAE 
8. Ibid.

9.ARAN. F. 142. Op. 1. Ed. xr. 45. L. 10. MAE

10. Moser Henry. Puteshestvie v strany Sredney Azii Kirgizskaya step -Russkiy TurkestanBuxara-Khiva zemli turkmen i Persii v stranax Sredney Azii. Putevye vpechatleniya Henrikha Mozera. 1882-1883.

11. Ibid.

12. Frederick XITTsEL. Swiss traveler Henry Moser and ego sredneaziatskaya collection. Vostok magazine svyshe. XXXI vyp. T. 201372 b.

13. Frederick Hittsel. Swiss traveler Henry Moser and ego sredneaziatskaya collection. Vostok magazine svyshe. XXXI vyp. T. 2013, p. 72.

14. Mozer Henry .. Travel to the lands of Central Asia Kyrgyz step - Russian TurkestanBukhara-Khiva land Turkmens and Persia in the lands of Central Asia. Putevye vpechatleniya Henrikha Mozera. 1882-1883.

15. Puteshestvie Anri Mozera v Buxaru i Xivu 1883. https://humus.livejournal.com/ 16. Frederick Hittsel. Swiss traveler Henry Moser and ego sredneaziatskaya collection. Turkestovedenie. From the materials of the international conference. September 12-14, 2013 Samarkand.

17. «Swiss traveler Heinrich Moser (1844 - 1923) v ekspeditsiyax Russkogo Geograficheskogo Obshchestva» http://helenika.ru/index.php 18. Ibid.

19. Baxronovna, R. D. (2019). French explorers' expeditions in Central Asia. International Journal on Integrated Education, 2(6), 253-256. 